\begin{tabular}{|l|r|r|}
\hline \multicolumn{2}{|c|}{ DJS Vol. 36 (2013) 39-46 } \\
\hline $\mathbf{1 9 6 9}$ & $\begin{array}{c}\text { Delta Journal of Science } \\
\text { Available online at } \\
\text { https://djs.journals.ekb.eg/ }\end{array}$ & \\
\hline Research Article & BOTANY \\
\hline
\end{tabular}

\title{
DIVERSITY IN MICROPYLE, HILUM AND LENS CHARACTERISTICS IN SEEDS OF THE MIMOSOIDEAE-LEGUMINOSAE
}

\author{
H. A. Hussein, N. M. George, A. Ghareeb and M. M. El- Dimerdash \\ Botany Department, Faculty of Science, Zagazig University
}

\begin{abstract}
The characteristics of micropyle, hilum and lens in seeds of 12 species and 3 subspecies representing 8 genera of the Mimosoideae were examined by Scanning Electron Microscope (SEM). The micropyle and hilum features proved useful in the delimitation of some taxa at the species and subspecies levels. The combination of lens characteristics (including the lens position in relation to hilum and the lens elevation concomitantly with the lens shape) offered indispensable criteria for separation of the taxa primarily at the species level and sometimes at the subspecies level as well as very rarely at the rank of genus. A key to the taxa investigated was provided based mainly upon the lens characteristics.
\end{abstract}

worthwhile to benefit from the facilities of the scanning electron microscope (SEM) to reveal as much of the seed

\section{INTRODUCTION}

Hard legume seeds invariably have three apertures: the micropyle, the hilum and the lens (an area of epidermal weakness) commonly occurring in that order (Polhill et al. 1981). Lersten et al. (1992) added that the lens in members of the Leguminosae is a circular to variously elongate area of modified seed coat and lies somewhere along the sagittal midline of the seed usually near the hilum on the opposite side of the micropyle. In some legume genera (e.g. Bauhinia) a fourth aperture, the pseudo-lens, lies next to the micropyle instead of the usual position of the true lens on the other side of the micropyle. The easily disrupted area of the lens is where water first enters the seed to stimulate germination and it regulates the rate of water movement into the seed (Manning and van Staden 1987a).

The range of morphological variation in the shape, size and position of the three apertures and the occurrence of the pseudo-lens in seeds of the Leguminosae (Fabaceae) is so wide that it made them a rich source of easily observable characteristics of immense value in the classification of the family (Brubaker et al. 1988; van Staden et al. 1989; Sahai 1999). Such aspects of variation were also a useful tool in the identification of numerous members of the Leguminosae at the generic, specific and infra-specific levels (Lersten and Gunn 1982; Manning and van Staden 1987b; Brubaker et al. 1988; Lersten et al. 1992; Sahai 1999; Hussein et al. 2002a \& b).

It is generally acknowledged that the distinction between some of the local representatives of the Leguminosae-Mimosoideae in Egypt is fraught with difficulty. For instance, apart from the dubious difference in the density of epidermal trichomes on the pods, it is almost impossible to separate Acacia tortilis subsp. raddiana from the type subspecies. It therefore seemed characteristics of some taxa of the Leguminosae-Mimosoideae

as possible and apply the results to resolving the difficulties encountered in their identification.

\section{Materials and Methods}

\section{Materials}

Fresh plant specimens containing mature dry pods of 12 species and three subspecies of the Mimosoideae were collected. Some of them were gained as mature dry pods (Table 1). The collected specimens include both native and horticultural ones. The identification of the collected specimens was achieved by the morphological comparison against authentic herbarium specimens kept at the herbarium of Orman Botanical Garden, Giza, Egypt. The scientific names and the author citations were rechecked according to Boulos (1999) and the website of the International Plant Names Index: www.ipni.org/ipni/query_ipni.html.

\section{Methods}

For SEM observations, at least two seeds from each specimen were examined. Whole seeds or portions of large-sized seeds were mounted on Copper stubs, coated with a thin layer of gold and examined using JEOL-JSM-5400 Scanning Electron Microscope at Electron Microscope Unit, Assiut University since 2003-2004. 
Table (1):The taxa studied with their locality and date of collection.

\section{${ }^{(*}$ Specimens collected from the Cairo University herbarium. \\ ${ }^{(* *)}$ Specimen collected from the herbarium of Orman Botanical Garden.}

\begin{tabular}{|c|c|}
\hline Taxa & Locality\& Date of collection \\
\hline Acacia cyanophylla Lindl. & $\begin{array}{l}\text { Parks at Zagazig Univ., Zagazig, } \\
\text { Egypt/April 2003. }\end{array}$ \\
\hline Acacia farnesiana $^{(*)}($ L.) Willd. & $\begin{array}{l}\text { Canal banks, Beni Swif, Egypt/June, } \\
2001 \text {. }\end{array}$ \\
\hline $\begin{array}{l}\text { Acacia nilotica (L.) Delile subsp. } \\
\text { nilotica }\end{array}$ & $\begin{array}{l}\text { Canal banks, Zagazig, Egypt/ } \\
\text { December, } 2003 \text {. }\end{array}$ \\
\hline $\begin{array}{l}\text { Acacia tortilis (Forssk.) Hayne } \\
\text { subsp.raddiana }{ }^{(*)} \text { (Savi) Brenan }\end{array}$ & El Tur, South Sinai, Egypt/June 2001. \\
\hline $\begin{array}{l}\text { Acacia tortilis (Forssk.) Hayne } \\
\text { subsp.tortilis }{ }^{(*)}\end{array}$ & El Tur, South Sinai, Egypt/June 2001. \\
\hline Albiziajulibrissin Durazz. & $\begin{array}{l}\text { Orman Botanical Garden, Giza, } \\
\text { Egypt/August 2004. }\end{array}$ \\
\hline Albizia lebbeck Benth. & $\begin{array}{l}\text { Salah Salem road, Cairo, Egypt/July, } \\
2003 \text {. }\end{array}$ \\
\hline $\begin{array}{l}\text { Dichrostachys cinerea (L.) Wight } \\
\text { \& Arn. }\end{array}$ & $\begin{array}{l}\text { Orman Botanical Garden, Giza, } \\
\text { Egypt/December, 2002 }\end{array}$ \\
\hline $\begin{array}{l}\text { Enterolobium contortisiliquum } \\
\text { (Vell.) Morong }\end{array}$ & The Zoo, Giza, Egypt/April, 2003. \\
\hline $\begin{array}{l}\text { Enterolobium cyclocarpum (Jacq.) } \\
\text { Griseb. }\end{array}$ & The Zoo, Giza, Egypt/April, 2003. \\
\hline $\begin{array}{l}\text { Faidherbia albida (Delile) A. } \\
\text { Chev. }\end{array}$ & $\begin{array}{l}\text { Agricultural Museum, Giza, } \\
\text { Egypt/April, 2003. }\end{array}$ \\
\hline $\begin{array}{l}\text { Inga dulcis (Roxb.) Willd. } \\
\text { Leucaena glauca (L.) Benth. }\end{array}$ & $\begin{array}{l}\text { The Zoo, Giza, Egypt/August, } 2004 . \\
\text { The Zoo, Giza, Egypt/April, } 2003 .\end{array}$ \\
\hline $\begin{array}{l}\left.\text { Prosopis farcta }{ }^{* *}\right) \text { (Banks \& } \\
\text { Sol.) Macbr. }\end{array}$ & $\begin{array}{l}\text { Bahariya Oasis, Egypt/December, } \\
2002 \text {. }\end{array}$ \\
\hline Prosopis juliflora(Sw.) DC. & The Zoo, Giza, Egypt/August 2003. \\
\hline
\end{tabular}

\section{RESULTS}

The seeds commonly have three apertures: the micropyle, hilum and lens. These apertures are altogether detected at one end of the seed towards the radicle tip. The lens is invariably located behind the hilum which separates it from the micropyle unless otherwise indicated. The previously mentioned term 'pseudolens' applied to the lens -like structure that lies next to the micropyle instead of the usual position behind the hilum was also adopted here to refer to the mound or the bulge-like structure that lies next to the micropyle. The characteristics of the micropyle, hilum and lens in seeds of the taxa studied could be described as follows (Figs. 1-15).

Acacia cyanophylla Lindl. (Fig. 1). The micropyle invisible. Hilum distinctively massive in size, more or less rounded in shape. Lens adnate to the hilum, located in a depression (i.e. depressed) contiguous to the depression containing the hilum. Lens discoid bulge-like in shape with its epidermis fissured.

Acacia farnesiana (L.) Willd. (Fig. 2). The micropyle Yshaped slit with a thickened rim and located adjacent to the hilum in a common depression also extending shallowly to include the lens. Hilum conspicuous i.e. its shape could not be definitely described. Lens adnate to the hilum and slightly depressed altogether with the hilum and micropyle in a common depression. Lens pyriform low bulge-like in shape.

Acacia nilotica (L.) Delile subsp. nilotica (Fig. 3).The micropyle slit-like in shape and located abutting against the hilum in a common shallow depression also including the lens. Hilum rounded with a funicular remnant. Lens adnate to the hilum, slightly depressed altogether with the hilum and micropyle in a common depression. Lens elliptic low bulgelike in shape with its epidermis fissured.

Acacia tortilis (Forssk.) Hayne subsp. raddiana (Savi) Brenan (Fig. 4). The micropyle slightly sunken slit-like and located abutting against the hilum. A mound seems to be another lens (here, termed as pseudolens) also detected next to the micropyle. Hilum elliptic. Lens located away from the hilum and micropyle. Lens mounded i.e. raised from the surrounding epidermal cells. Lens discoid bulge-like in shape with its epidermis fissured.

Acacia tortilis (Forssk.) Hayne subsp. tortilis (Fig. 5). The micropyle Y-shaped slit with a thickened rim. Hilum more or less rounded. Lens undetectable but a pseudolens detected to be located next to the micropyle. The micropyle and pseudolens located in a depression adjacent to the hilum.

Albizia julibrissin Durazz. (Fig. 6).. The micropyle slightly sunken, slit-like and located abutting against the hilum. A pseudolens detected to be located next to the micropyle. Hilum more or less rounded. Lens located away from the hilum and slightly mounded in a separate shallow depression with a thickened boundary. Lens discoid bulge-like in shape.

Albizia lebbeck Benth. (Fig. 7). The micropyle sunken, deltoid slit-like and located adjacent to the hilum. Hilum elliptic with a funicular remnant. Lens located away from the hilum and slightly depressed in a separate depression with an exaggerated thickened boundary. Lens oval-oblong plain in shape.

Dichrostachys cinerea (L.) Wight \& Arn. (Fig. 8). The micropyle punctiform $i$. e. punctate aperture and located abutting against the hilum in a common depression. Hilum more or less rounded. Lens located away from the hilum and slightly depressed in a separate depression with a thickened boundary. Lens oval bulge-like in shape.

Enterolobium contortisiliquum (Vell.) Morong (Fig. 9). The micropyle punctiform and located abutting against the hilum. Hilum more or less rounded with a funicular remnant. Lens located away from the hilum, mounded in a separate shallow depression with a thickened boundary. Lens dome-like in shape with its epidermis fissured.

Enterolobium cyclocarpum (Jacq.) Griseb. (Fig. 10). The micropyle V-shaped slit with a thickened rim and located abutting against the hilum. Hilum more or less rounded with a funicular remnant. Lens characters similar to that in seeds of E. contortisiliquum.

Faidherbia albida (Delile) A. Chev. (Fig. 11). The micropyle slightly sunken, irregular slit-like with thickened and obviously striated rim and located adjacent to the hilum. Hilum elongate with a funicular remnant. Lens adjacent to the hilum and located in a depression. Lens long deep furrow in shape.

Inga dulcis (Roxb.) Willd. (Fig. 12). The micropyle slit-like and located abutting against the hilum in a common depression also including the lens. A pseudolens detected to be located next to the micropyle. Hilum elliptic with part of 
the funicular remnant dislodged. Lens adnate to the hilum and slightly depressed together with the hilum and micropyle in a common shallow depression. Lens elongate oblong bulge in shape with part of its epidermis dislodged.

Leucaena glauca (L.) Benth. (Fig. 13). The micropyle crescentic slit-like and located abutting against the hilum in a common depression also including the lens. Hilum elliptic with a funicular remnant. Lens located away from both the hilum and micropyle in a common depression. Lens oval plain in shape with its epidermis dislodged.

Prosopis farcta (Banks \& Sol.) Macbr. (Figs. 14 a \& b). The micropyle crescentic slit-like and located abutting against the hilum in common depression. Hilum more or less rounded with a funicular remnant. Lens located in a separate depression away from the depression containing both the hilum and micropyle. Lens oval plain in shape with its epidermis dislodged (Fig. 14 b).

Prosopis juliflora (Sw.) DC. (Fig. 15). The micropyle crescentic slit-like and located abutting against the hilum in a common depression. Hilum more or less rounded with a funicular remnant. Lens adjacent the hilum and mounded. Lens dome-like in shape.

The micropyle and hilum characteristics among the taxa studied are outlined in Table 2.

Table (2).Micropyle and hilum characteristics in seeds of the Mimosoideae.

Abbreviations:

${ }^{(*)}=A$ slit-like with a thickened rim; ${ }^{(* *)}$ A slit-like with thickened and obviously striated rim; $C=C$ Conspicuous i.e. its shape could not be definitely described; E= Elliptic with a funicular remnant; $E_{1}=$ Elliptic with part of the funicular remnant dislodged; El= Elongate with a funicular remnant; $M=$ Micropyle located adjacent to the hilum in a depression extending shallowly including the lens; $M_{1}=$ Micropyle located abutting against the hilum in a common depression also including the lens $M_{2}=$ Micropyle slightly sunken and located abutting against the hilum; $M_{3}=$ Micropyle and pseudolens in a depression adjacent to the hilum; $M_{4}=$ Micropyle sunken in a depression adjacent to the hilum; $M_{5}=$ Micropyle located abutting against the hilum in a common depression; $M_{6}=$ Micropyle abutting against the hilum; $M_{7}=$ micropyle slightly sunken and adjacent to the hilum; $R_{1}=$ More or less rounded; $R_{2}=$ Rounded. $U D=$ Undetected

\begin{tabular}{|l|l|l|l|}
\hline \multirow{2}{*}{ Characters } & \multicolumn{2}{l|}{ Micropyle } & Hilum shape \\
\cline { 2 - 4 } & Shape & Position & \\
\hline Acacia cyanophylla & Invisible & $\mathrm{UD}$ & $\begin{array}{l}\mathrm{R}_{1} \& \text { massive } \\
\text { in size }\end{array}$ \\
\hline Acacia farnesiana & $\begin{array}{l}\text { Y-shaped } \\
\text { slit( }\end{array}$ & $\mathrm{M}$ & $\mathrm{C}$ \\
\hline Acacia nilotica subsp. nilotica & Slit-like & $\mathrm{M}_{1}$ & $\mathrm{R}_{2}$ \\
\hline Acacia tortilis subsp. raddiana & Slit-like & $\mathrm{M}_{2}$ & $\mathrm{E}$ \\
\hline Acacia tortilis subsp. tortilis & $\begin{array}{l}\text { Y-shaped } \\
\text { slit( }\end{array}$ & $\mathrm{M}_{3}$ & $\mathrm{R}_{1}$ \\
\hline Albizia julibrissin & Slit-like & $\mathrm{M}_{2}$ & $\mathrm{R}_{1}$ \\
\hline Albizia lebbeck & $\begin{array}{l}\text { Deltoid slit- } \\
\text { like }\end{array}$ & $\mathrm{M}_{4}$ & $\mathrm{E}$ \\
\hline Dichrostachys cinerea & Punctiform & $\mathrm{M}_{5}$ & $\mathrm{R}_{1}$ \\
\hline Enterolobium contortisiliquum & Punctiform & $\mathrm{M}_{6}$ & $\mathrm{R}_{1}$ \\
\hline Enterolobium cyclocarpum & $\begin{array}{l}\text { V-shaped } \\
\text { slit }\end{array}$ & $\mathrm{M}_{6}$ & $\mathrm{R}_{1}$ \\
\hline Faidherbia albida & $\begin{array}{l}\text { Irregular } \\
\text { slit( }{ }^{(*)}\end{array}$ & $\mathrm{M}_{7}$ & $\mathrm{El}$ \\
\hline Inga dulcis & Slit-like & $\mathrm{M}_{1}$ & $\mathrm{E}_{1}$ \\
\hline Leucaena glauca & $\begin{array}{l}\text { Crescentic } \\
\text { slit-like }\end{array}$ & $\mathrm{M}_{1}$ & $\mathrm{E}$ \\
\hline Prosopis farcta & $\begin{array}{l}\text { Crescentic } \\
\text { slit-like }\end{array}$ & $\mathrm{M}_{5}$ & $\mathrm{R}_{1}$ \\
\hline Prosopis juliflora & $\begin{array}{l}\text { Crescentic } \\
\text { slit-like }\end{array}$ & $\mathrm{M}_{5}$ & $\mathrm{R}_{1}$ \\
\hline
\end{tabular}

More detail will be given, here, to the variability in the characteristics of the lens including: the lens position in relation to hilum, the lens elevation in relation to the surrounding epidermis and the lens shape as follows:

a. Lens position in relation to the hilum and the lens elevation (Figs. 1-15):

1. Lens undetected; in Acacia tortilis subsp. tortilis (Fig. 5) but a pseudolens i.e. a lens- like structure is located next to the micropyle.

2. Lens adnate to the hilum and located in a depression (i.e. depressed) contiguous to the depression containing the hilum; in Acacia cyanophylla (Fig. 1).

3. Lens adnate to the hilum and slightly depressed altogether with the hilum and micropyle in a common depression; in Acacia farnesiana (Fig. 2), A. nilotica subsp. nilotica (Fig. 3) and Inga dulcis (Fig. 12). In seeds of Inga dulcis a pseudolens is also located next to the micropyle.

4. Lens adjacent to the hilum and located in a depression; in Faidherbia albida (Fig. 11).

5. Lens adjacent to the hilum and mounded i.e. raised from the surrounding epidermal cells; in Prosopis juliflora (Fig. 15).

6. Lens located away from the hilum and mounded; in Acacia tortilis subsp. raddiana (Fig. 4). A pseudolens is also found next to the micropyle.

7. Lens located away from the hilum and micropyle in a common depression; in Leucaena glauca (Fig. 13).

8. Lens located in a separate depression away from the depression containing both the hilum and micropyle; in Prosopis farcta (Fig. 14)

9. Lens located away from the hilum and micropyle and mounded in a separate shallow depression with a thickened boundary; in Albizia julibrissin (Fig. 6), Enterolobium contortisiliquum and E. cyclocarpum (Figs. $9 \&$ 10). In seeds of Albizia julibrissin a pseudolens is located next to the micropyle. 
10. Lens located away from the hilum and micropyle and slightly depressed in a separate shallow depression either with a thickened boundary in Dichrostachys cinerea (Fig. 8), or with an exaggerated boundary in Albizia lebbeck (Fig. 7).

a. Lens shape (Figs. 1-15):

1. Undetected: in Acacia tortilis subsp. tortilis (Fig. 5).

2. Long deep furrow: in Faidherbia albida (Fig. 11).

3. Oval plain: in Prosopis farcta (Fig. 14) and Leucaena glauca (Fig. 13) in which the lens with part of its epidermis dislodged.

4. Oval-oblong plain: in Albizia lebbeck (Fig. 7).

5. Discoid bulge-like: in Acacia cyanophylla (Fig. 1), Acacia tortilis subsp. raddiana (Fig. 4) and Albizia julibrissin (Fig. 6). In Acacia cyanophylla and A. tortilis subsp. raddiana, the lens with its epidermis fissured.

6. Pyriform low bulge-like: in Acacia farnesiana (Fig. 2).

7. Elliptic low bulge-like with its epidermis fissured: in Acacia nilotica subsp. nilotica (Fig. 3).

8. Elongate oblong bulge with its epidermis fissured: in Inga dulcis (Fig. 12).

9. Oval bulge-like: in Dichrostachys cinerea (Fig. 8).

10. Dome-like: in Prosopis juliflora (Fig. 15), Enterolobium contortisiliquum (Fig. 9) and E. cyclocarpum (Fig. 10). In the latter two the lens with its epidermis fissured.

\section{Discussion}

It is evident that every taxon included in the present study has its unique combination of seed attributes which does not exist in its entisity in any other taxon (Table 2 and Figs. 1-15). Hence, the use of seed characters in the identification of members of the Leguminosae-Mimosoideae.

The lens characteristics, here, included position of the lens in relation to hilum, the lens elevation and the lens shape. These characteristics proved themselves as very useful criteria in the differentiation of the taxa investigated except the two investigated species of Enterolobium which remained only delimited at the generic level. The combination of lens characteristics with some of those of the micropyle helped in the differentiation of the taxa studied at the species and subspecies levels. The following key is suggested to the taxa studied:

A. Lens undetectable Acacia tortilis subsp. tortilis

AA. Lens detectable

I. Lens adnate to the hilum

i. Lens depressed contiguous to the depression containing the hilum

but the micropyle invisible; hilum massive in size..Acacia cyanophylla

ii. Lens slightly depressed together with the hilum and micropyle in a

common depression; hilum not massive in size

- Lens pyriform low bulge-like farnesiana Acacia

•• Lens elliptic low bulge-like Acacia nilotica subsp. nilotica

Lens elongate oblong bulge Inga dulcis

II. Lens adjacent to the hilum

- Lens mounded and dome- like; micropyle crescentic slit .Prosopis juliflora

-• Lens depressed and long deep furrow; micropyle irregular slit with thick striated rim. Faidherbia albida

III. Lens depressed away from the depression of both hilum and micropyle. Prosopis farcta

IV. Lens located away from both the hilum and micropyle i. Lens mounded i.e. raised from the epidermal cells on a level. Acacia tortilis subsp. raddiana

ii. Lens in a common depression with the hilum and micropyle. ..Leucaena glauca

iii. Lens slightly depressed in a separate depression with a thickened boundary

- Lens oval-oblong plain; micropyle deltoid slit...Albizia lebbeck

-• Lens oval bulge; micropyle punctiform....Dichrostachys cinerea

iv. Lens mounded in a separate depression with a thickened boundary

- Lens discoid bulge-like with a thick boundary.................Albizia julibrissin

•• Lens dome-like with a thick boundary.......Enterolobium

- Micropyle punctiform............E. contortisiliquum

-- Micropyle V-shaped.............E. cyclocarpum

\section{References}

Boulos, L. (1999). Flora of Egypt. Vol. I (AzollaceaeOxalidaceae). Al Hadara Publishing, Cairo, Egypt, pp. 362372.

Brubaker, C. L.; Lersten, N. R. and Gunn, C. R. (1988). Lens morphology in seeds of Mimosoideae (Leguminosae). Journal of the Iowa Academy of Science, 95: 1-16.

Hussein, H. A.; Khalifa, S. F.; Ghareeb, A. and Fawzi, N. (2002a). Taxonomic importance of seed characteristics of some species of Cassia and Senna (Subfamily: Caesalpinioideae-Leguminosae). Egyptian Journal of Biotechnology, 12: 248-265.

Hussein, H. A.; Khalifa, S. F.; Ghareeb, A. and Fawzi, N. (2002b). Taxonomic criteria of the characteristic features in seeds of some selected species of CaesalpinioideaeLeguminosae. Egyptian Journal of Biotechnology. 12: 280298. 
Lersten, N. R. and Gunn, C. R. (1982). Testa characters in tribe Vicieae, with notes about tribes Abreae, Cicereae and Trifolieae (Fabaceae). U S Department of Agriculture Technical Bulletin 1667: 1-40.

Lersten, N. R.; Gunn, C. R. and Brubaker, C. L. (1992). Comparative morphology of the lens on legume (Fabaceae) seeds, with emphasis on species in subfamilies Caesalpinioideae and Mimosoideae. U S Department of Agriculture Technical Bulletin, 1791: 1-44.

Manning, J. C. and van Staden, J. (1987a). The role of the lens in seed imbibition and seedling vigour of Sesbania punicea (Cav.) Benth. (Leguminosae: Papilionoideae). Annals of Botany (London), 59: 705-713.

Manning, J. C. and van Staden, J. (1987b). The systematic significance of the testa anatomy in the Leguminous- an illustrated survey. South African Journal of Botany, 53: 210230 .

Polhill, R. M.; Raven, P. H. and Stirton, C. H. (1981). Evolution and systematics of the Leguminosae. In: Advances in Legume Systematics. Polhill, R. M. and Raven, P. H. (eds.) Vol. 2, Part 1, Kew, England. pp. 1- 26.

Sahai, K. (1999). Structural diversity in the lens of the seeds of some Cassia L. (Caesalpinioideae) species and its taxonomic significance. Phytomorphology, 49: 203-208.

van Staden, J.; Manning, J. C. and Kelly, K. M. (1989). Legume seeds-the structure: function equation. In: Advances in Legume Biology. Stirton, C. H. and Zarucchi, J. L. (eds.). Monographs in Systematic Botany from the Missouri Botanical Garden, 29: 417-450.
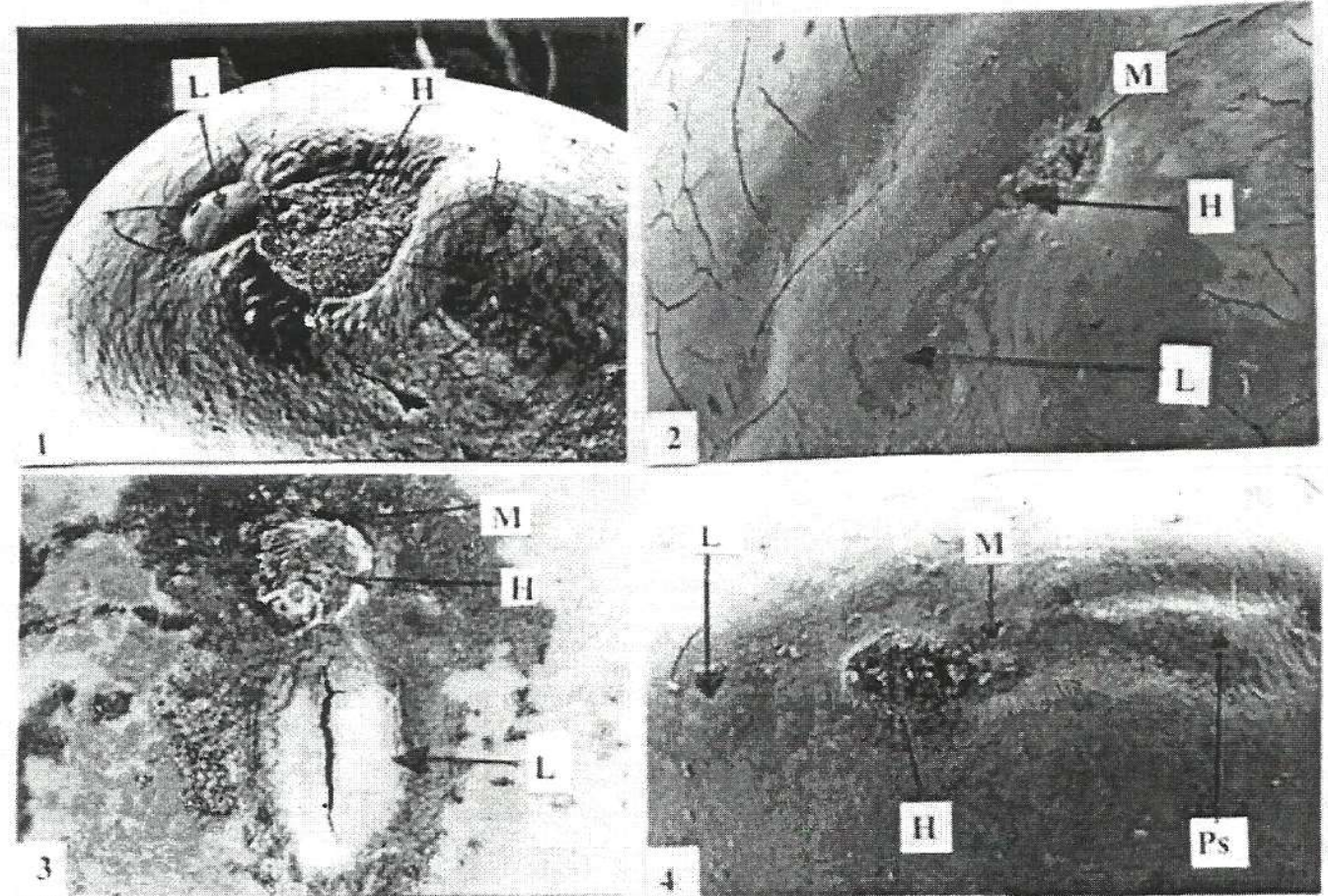

\section{2}

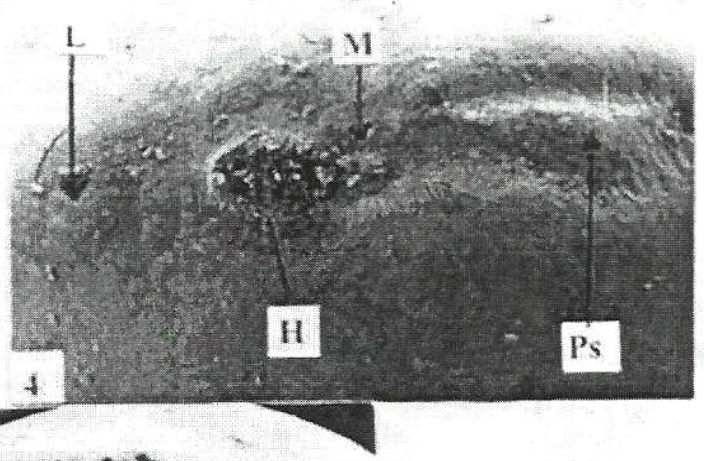



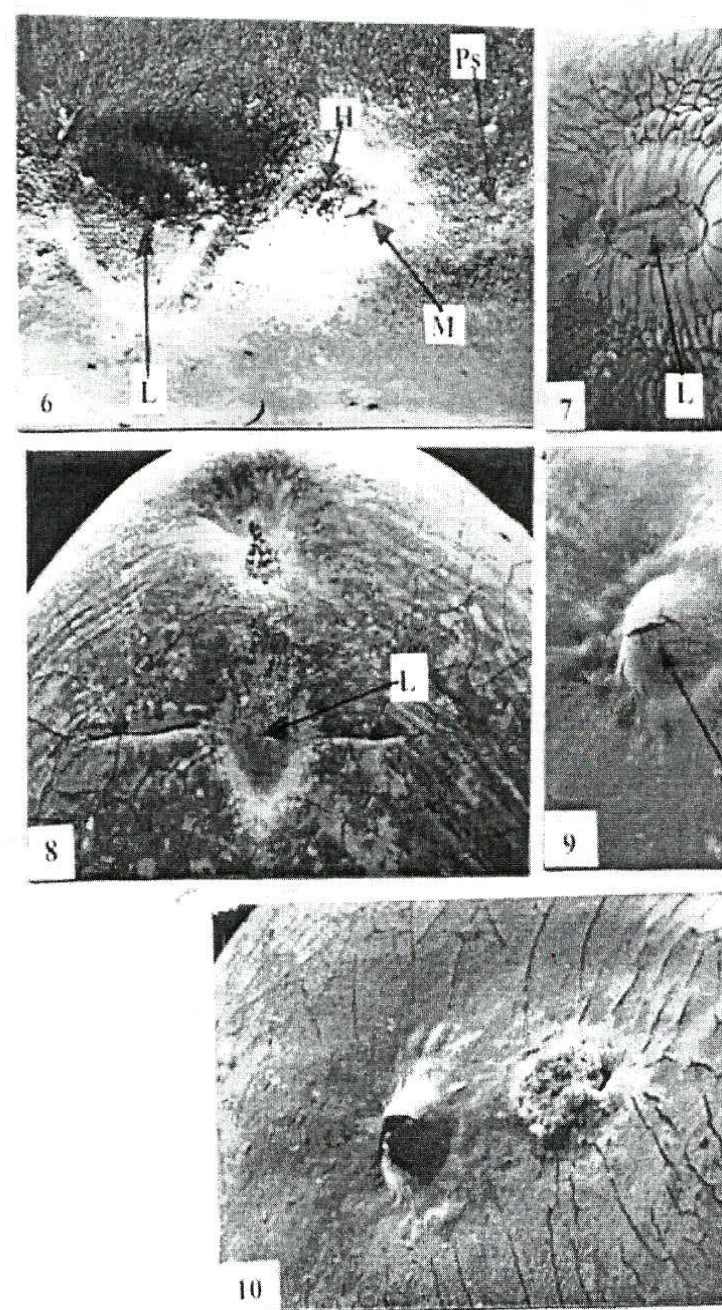

Figs. 6-10. Photomicrographs showing micropyle, characteristics. 6. Albizia julibrissin, $\mathrm{x}=100 ; 7$. A. le Dichrostachys cinerea, $\mathrm{x}=100 ; 9$. Enterolobium contor 10. E. cyclocarpum $\mathrm{x}=75 ; \mathbf{M}=$ micropyle; $\mathbf{H}=$ hilu pseudolens. 

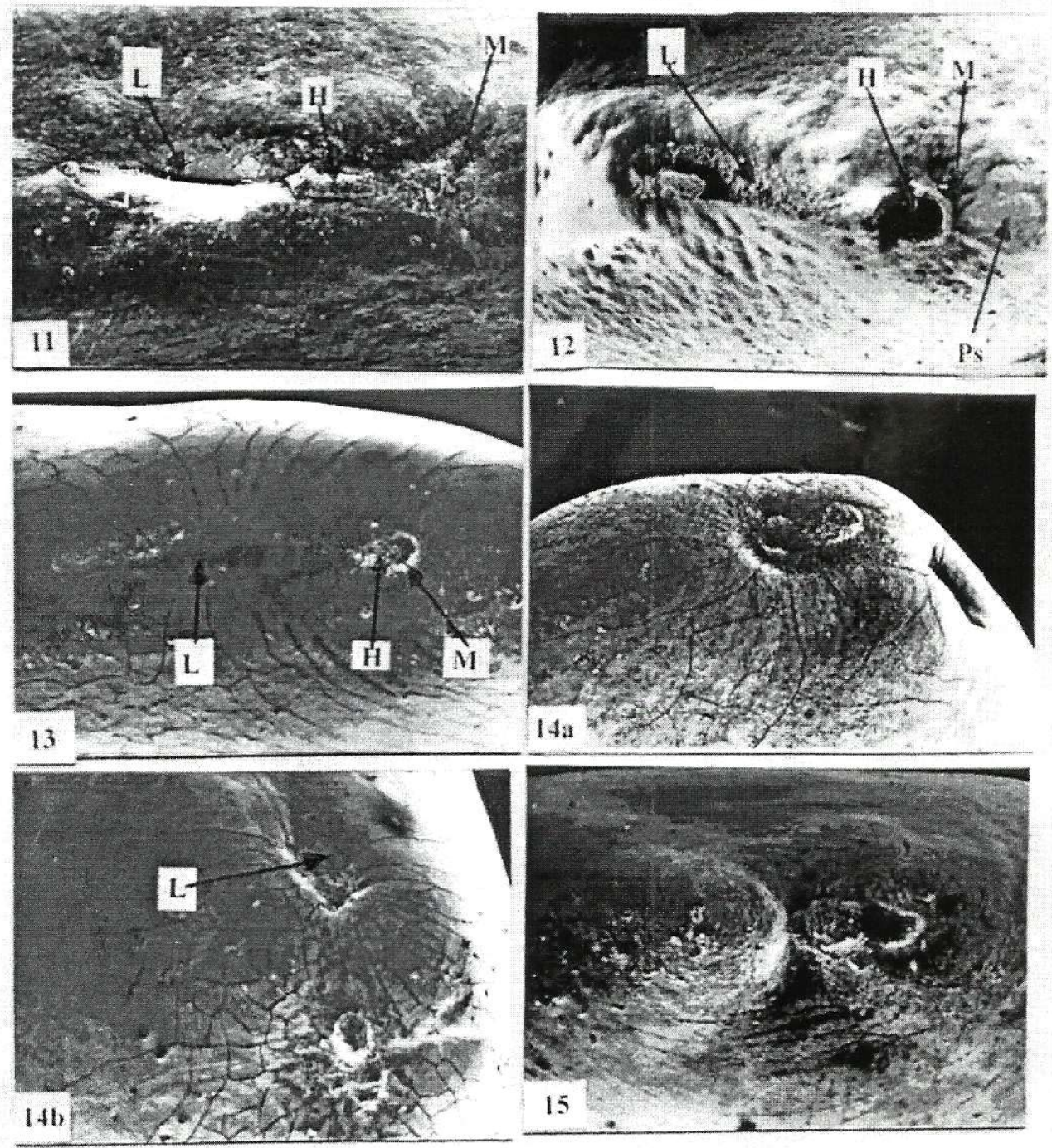

Figs. 11-15. Photomicrographs showing micropyle, hilum and lens characteristics. 11. Faidherbia albida, $\mathrm{x}=100 ; 12$. Inga dulcis, $\mathrm{x}=35$; 


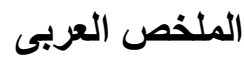

\section{التنوع فى خصائص النقير والسرة والعلسة فى بذور تحت الفصيلة الطحية_الفصيلة القرنية}

حسين عبدالباسط حسين - نيللى ميشيل جورج - أحمد غريب- مروة محسن الدمرداش

$$
\text { قسم النباتـ كلية العلوم- جامعة الزقازيق }
$$

تمـت دراسـة خصـائص النقير والسـرة والعدسـة باستخدام المجهر الإلكترونسى الماسـح فـى بـذور خمس عشـرة وحدة تصنيفية-جمعت من مصر - وتتنمى إلى تحت الفصيلة الطلحية من الفصيلة القرنية. وتهدف الدر اسـة إلى استخلاص خصائصـها

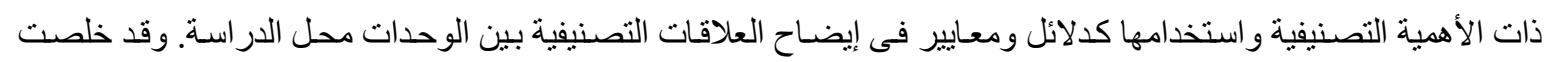
الدراسة إلى عدد من النتائج نوجز ها فيما يلى: التباين فى صفات كل من النقير و السرة يمثل أداة هامـة للتمبيز عند مستوى النوع وكنللك تحت النوع فى بعض من الوحدات التصنيفية محل الدراسة.

خصائص العدسة من حيث: موضعها بالنسبة للسرة، ومستوى ارتفاعها بالنسبة لخلايا البشرة المحيطة، وكذلك أشكالها المتباينة، تمثل صفات تتخيصية لا يمكن إغفالها فى المعالجات التصنيفية فى تحت الفصيلة الطلحية. وقد تم التوصل إلى بناء مفتاح اصطناعى لتمييز الوحدات التصنيفية محل الدراسة يعتمد بالأساس على خصائص العدسة فى بذور ها. 